\title{
Utilization of Papaya Seeds as Natural Coagulant for Synthetic Textile Coloring Agent Wastewater Treatment
}

\author{
Hans Kristianto", Maria Angelina Kurniawan", Jenny N M Soetedjo ${ }^{\#}$ \\ \# Department of Chemical Engineering, Faculty of Industrial Technology, Parahyangan Catholic University, Ciumbuleuit 94, Bandung, \\ 40141, Indonesia \\ E-mail: hans.kristianto@unpar.ac.id, jenny.novianti@unpar.ac.id
}

\begin{abstract}
Textile wastewater contains many pollutants which is hazardous if directly discharged. Various technologies such as adsorption, advanced oxidation processes, biological treatment, membrane technology, coagulation, and flocculation have been explored and utilized to treat textile wastewater. However, coagulation followed by flocculation is still widely used. Usually, inorganic salts such as alum, ferric chloride, PAC, are widely used to treat textile wastewater. However, utilization of inorganic salts poses some drawbacks, such as high coagulant cost, a large volume of sludge produced, and potential health problems if the water is consumed. In this study, we explore the utilization of natural coagulant as an alternative to inorganic salts to treat textile wastewater. This study describes the utilization of papaya seeds powder as a natural coagulant for synthetic textile wastewater of drimarene dark red (DDR) with an initial concentration of $10 \mathrm{mg} / \mathrm{L}$. The effect of coagulant dosage and $\mathrm{pH}$ to the \%removal of color in wastewater was studied using central composite design. The potential active functional groups in papaya seeds powder were characterized using Fourier Transform Infrared Spectroscopy (FTIR). It was found that papaya seeds powder contained $-\mathrm{OH}$, $-\mathrm{NH}$, $\mathrm{C}=\mathrm{O}$ functional groups that indicate good potential as natural coagulant. The cubic model obtained was in a good fit with experimental data, which was shown in the R-squared value of 0.995 . It was found that coagulant dosage, $\mathrm{pH}$, and its interaction were significant to the removal of synthetic dye in wastewater. The decrease of $\mathrm{pH}$ gave higher \%removal due to protonation of papaya seeds powder active coagulating agent resulting in better electrostatic interaction with dyes. The increase of dosage also gave an increase in \%removal until its optimum condition. After optimum condition, the \% removal decreased due to colloid re-stabilization. The optimum condition was obtained at a dosage of $0.57 \mathrm{~g} / \mathrm{L}$, and $\mathrm{pH} 1.97$ with $84.77 \%$ of predicted color removal and this result was in agreement with experimental response value.
\end{abstract}

Keywords — drimarene dark red (DDR); natural coagulant; papaya seeds powder; reactive dye.

\section{INTRODUCTION}

Textile industry is one of the biggest industry that uses water and many chemicals during its process. The spillage and wastewater from the process usually have color, high in biological oxygen demand (BOD) and chemical oxygen demand (COD), and also toxic chemicals [1]. In many developing countries, the wastewater is usually directly discharged to the river body without any treatment. This severe possesses a threat to flora and fauna in the river, and also to people that use the water for daily life. Various technologies such as coagulation/flocculation [1], adsorption [2], advanced oxidation processes (AOPs) [3], biological treatment [4] and membrane technology [5] have been utilized to treat textile wastewater.

Adsorption technology utilizes activated carbon, silica gel, and biomass as adsorbents. This technology is said to be useful for various dyes removal, especially for dyes that too stable for conventional treatment methods [2]. Adsorption technology has some drawbacks, such as difficulties in regeneration, expensive and high energy consuming adsorbent production (activated carbon), and the high cost of disposal [1], [2]. Utilization of biomass (e.g., wood chips, fruit peel, and nutshell) has been studied as an alternative to widely used activated carbon. However, their commercialization still meets some difficulties [6].

Advanced oxidation processes (AOPs) consists of various techniques such as ozone oxidation, ozone/ UV, hydrogen peroxide/ UV, ozone/ hydrogen peroxide, Fenton, UV/ Fenton, UV/ TiO2 [3], [7]. All previously mentioned techniques have one purpose, which is to produce hydroxyl free radical (HO•) as a strong oxidant. The produced hydroxyl free radical then destroys the chemical bond of dyes and chemicals in textile wastewater, thus lowering its BOD, COD value. Some drawbacks of this technology are high in cost, the formation of byproducts, sludge generation [8]. The biological treatment uses a mixed culture of microorganisms rather than single species [4]. The degradation of azo dyes in textile wastewater consists of two 
steps, firstly degradation of azo compound anaerobically into the smaller compound, then secondly, metabolizing the smaller compounds under aerobic condition. This method has some advantages, such as environmentally friendly, less sludge volume produced, and low cost [9]. However, there are some drawbacks for application of this technology such as slow process, needs of nutrients, and limited operation temperature [1].

Membrane technology, such as microfiltration, ultrafiltration, nanofiltration, and reverse osmosis, has been studied to treat textile wastewater and recycle water in the textile industry. Membrane filtration has been proven effective for textile wastewater treatment; however, due to high investment and operating cost, its application is limited to pilot scale [10]. Disadvantages of membrane filtration are relatively expensive and the production of concentrated sludge that needs further treatment [1], [2].

Although previously explained technologies have their great potential for textile wastewater treatment, coagulation/flocculation process is still widely used, either alone or combined with biological treatment, to remove suspended solids, organic matter, and color from textile wastewater [11]. The phenomenon of colloid destabilization is called coagulation, while the term flocculation refers to the formation of agglomerates following coagulation process.

There are four colloid destabilization mechanisms in water treatment, namely double-layer compression, charge neutralization, antiparticle bridging, and sweep flocculation [12]. Double layer compression happens due to high electrolytes concentration thus compressing the double layer surrounding colloid particles. The effect of the compressed double layer is a lower repulsive force, thus making coagulation possible. Charge neutralization happens as oppositely charged colloid are adsorbed on the surface of coagulant polymer resulting zero zeta potential which makes coagulation possible. Interparticle bridging is usually caused by long-chain polymer coagulant that has segments to bridge colloid particle together. Sweep flocculation takes place when the large dosage of coagulant is used, then entrapping the colloid within precipitating coagulant. Between this four mechanism, charge neutralization and interparticle bridging are usually found as coagulation mechanism for natural coagulants [12].

An inorganic coagulant, such as aluminum sulfate, ferric chloride, poly aluminum chloride has been widely used to treat wastewater. However, these coagulants have some drawbacks, such as the potential cause of health problem (Alzheimer, dementia), relatively high coagulant cost, and large sludge volume [12]. Natural coagulants have been extensively studied to overcome these drawbacks. Generally, natural coagulants could be classified as plant-based and non-plant based coagulant. Non-plant based coagulant usually comes from marine resources, such as chitosan [13] and alginate [14]. Various plant-based natural coagulants, such as Moringa oleifera [15], Moringa stenopelata [16], Plantago ovata [17], potato starch [18], okra (A. esculentus) [19] have been studied to treat textile wastewater. Utilization of these natural coagulants has some advantages, namely, lower coagulant cost, easily obtained, biodegradable, low toxicity, and producing smaller sludge volume [20] therefore natural coagulants have much potential for the alternative of wastewater treatment.

Mainly, there are three steps of preparation plant-based coagulant [12]. Primary treatment consists of preparation such as removing undesired parts, followed by drying and pulverization. Secondary treatment focuses on the extraction of the active coagulating agent from the plant. Finally, the tertiary process focuses on purification by using some methods such as dialysis, ion exchange, and precipitation.

Papaya (Carica papaya) is one of the tropical fruits that is easily found in South America and Asia, especially Indonesia. Papaya fruit flesh is known for its high nutrition and medicinal-pharmacological properties [21], while its seeds are inedible due to the presence of some toxicants such as phytates, glucosinolates, and tannins [22]. Papaya seeds have been used to treat turbid water with fecal bacteria [23], however to the best of author knowledge, its application to treat textile wastewater has never been studied before. In this study, we utilized papaya seeds powder as a coagulant to treat synthetic reactive dyes (DDR) wastewater. The effect of $\mathrm{pH}$ and coagulant dosage to the removal of color was studied using central composite design to find its optimum condition.

\section{MATERIAL AND METHOD}

\section{A. Papaya Seeds Powder}

Papaya was obtained from the local market in Bandung, West Java, Indonesia. Its seeds were collected and repeatedly washed to remove impurities, followed by oven drying at $110^{\circ} \mathrm{C}$ for 10 hours. Dried seeds were then crushed and sieved to obtained papaya seeds powder with a size of 40-50 mesh. These dried papaya seeds powder then stored in a desiccator and was used as coagulant without further treatment. Papaya seeds powder was also analyzed using FTIR (Shimadzu FTIR 8400, $\mathrm{KBr}$ pellet method) to qualitatively observe the possible active coagulant component in the seeds.

\section{B. Coagulation Tests}

Drimaren Dark Red (DDR) HF-CD solution was made by dissolving 10mg DDR powder in $1 \mathrm{~L}$ aquadest, and its $\mathrm{pH}$ was adjusted using $\mathrm{HCl}$ or $\mathrm{NaOH} 0.1 \mathrm{~N}$. The coagulation and flocculation experiments were carried out using jar test method in $1 \mathrm{~L}$ beaker glass. Initial wastewater sample was measured before coagulant addition to obtaining its initial concentration. Papaya seeds powder was added with various dosage and rapidly mixed at $200 \mathrm{rpm}$ for 1 minute, followed by slow mixing at $60 \mathrm{rpm}$ for 30 minutes. These mixtures were then left for 1 hour to settle down. $10 \mathrm{~mL}$ of sample was collected $5 \mathrm{~cm}$ below the surface level to determine its concentration. Wastewater concentration was measured using spectrophotometer (Thermo Scientific Genesys 20) at a maximum wavelength of $525 \mathrm{~nm}$.

\section{Design of experiment}

Central composite design was used to the obtained optimum condition of two main variables, namely papaya seeds powder dosage $(\mathrm{g} / \mathrm{L})$ and wastewater $\mathrm{pH}$. The response measured was \%removal of color in the wastewater, 
calculated using Eq. 1., where $\mathrm{Ci}$ and $\mathrm{Cf}$ are initial and final concentration $(\mathrm{mg} / \mathrm{L})$.

$$
\text { Gremoval }=\frac{a-c r}{a} \times 100 \%
$$

The schematic diagram of central composite design used is presented in Fig 1 and the design matrix used is presented in Table 1 with five replications of the center point. The obtained response was analyzed using Design Expert software version 7.0.0 with various models from linear to cubic were examined to fit the data obtained from the experiment. The best fit model was determined by its analysis of variance (ANOVA). Optimum condition was then obtained from the model, and its confirmation was done in triplicate.

TABLE I

LEVELS OF VARIABLES TESTED

\begin{tabular}{|l|l|l|l|l|l|}
\hline Variables & $-\alpha$ & -1 & 0 & +1 & $+\alpha$ \\
\hline $\begin{array}{l}\text { Dosage } \\
(\mathrm{g} / \mathrm{L})\end{array}$ & 0.15 & 0.25 & 0.5 & 0.75 & 0.85 \\
\hline $\mathrm{pH}$ & 1.29 & 1.5 & 2.0 & 2.5 & 2.71 \\
\hline
\end{tabular}

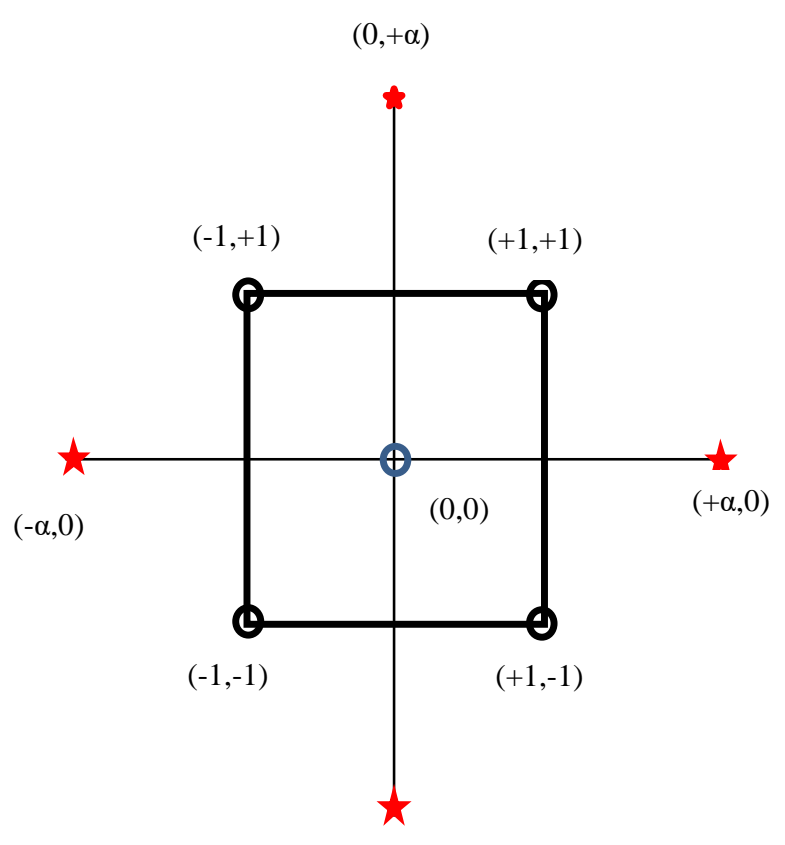

$(0,-\alpha)$

Fig 1. Schematic diagram of central composite design (CCD)

\section{RESULTS AND DISCUSSION}

\section{A. FTIR Analysis}

FTIR analysis has been used in previous studies to observe functional groups that present in plant-based coagulant [24]. The FTIR spectra of papaya seeds powder are presented in Fig 1, and infrared absorptions of some functional groups are presented in Table 2. The papaya seeds powder had a strong peak at $3438.8 \mathrm{~cm}^{-1}$ indicating the presence of O-H and N-H stretching [17], [25], and a peak indicated the presence of symmetrical and asymmetrical C-H at $2925.8 \mathrm{~cm}^{-1}$ and $2854.5 \mathrm{~cm}^{-1}$ respectively [26], [27]. The peak of $\mathrm{C}=\mathrm{O}$ ester groups was indicated at $1745.5 \mathrm{~cm}^{-1}$ [28] and $1544.9 \mathrm{~cm}^{-1}$ indicating amide functional groups [29]. It is known that papaya seeds have a high content of carbohydrates, proteins, and fat [22] that are in agreement with functional groups identified in FTIR analysis. The high content of functional groups indicates the good possibility for removal of contaminants from water [24].

\section{B. Model Fitting}

The results obtained from the jar test experiments are presented in Table 3 . These results were then analyzed to obtain the optimum condition for coagulation of DDR. The ANOVA showed that cubic polynomial was the most suitable model for the process. The ANOVA is presented in Table 4, and the equation of the model in real variables is presented in Eq 2.

$$
\begin{aligned}
\text { \%removal }= & 347.362-1037.694 * \text { Dosage }-254.000 * \mathrm{pH}+ \\
& 1045.243 * \text { Dosage } * \mathrm{pH}+159.334 * \text { Dosage }^{2}+ \\
& 43.082 * \mathrm{pH}^{2}-207.6453 * \text { Dosage }^{2} \mathrm{pH}^{2}- \\
& 162.625 * \text { Dosage }^{2} \mathrm{pH}
\end{aligned}
$$

This model gave R-squared of 0.995, with good Adjusted R-squared and Predicted R-squared and model's p-value < 0.05 at $90 \%$ level of significance, indicating good fit and suitability of the model representing the relationship of variables. This result is also shown in the predicted vs actual graph, presented in Fig 2. In this study, it was obtained that dosage, $\mathrm{pH}$, and its interaction was significant variables to the removal of DDR wastewater.

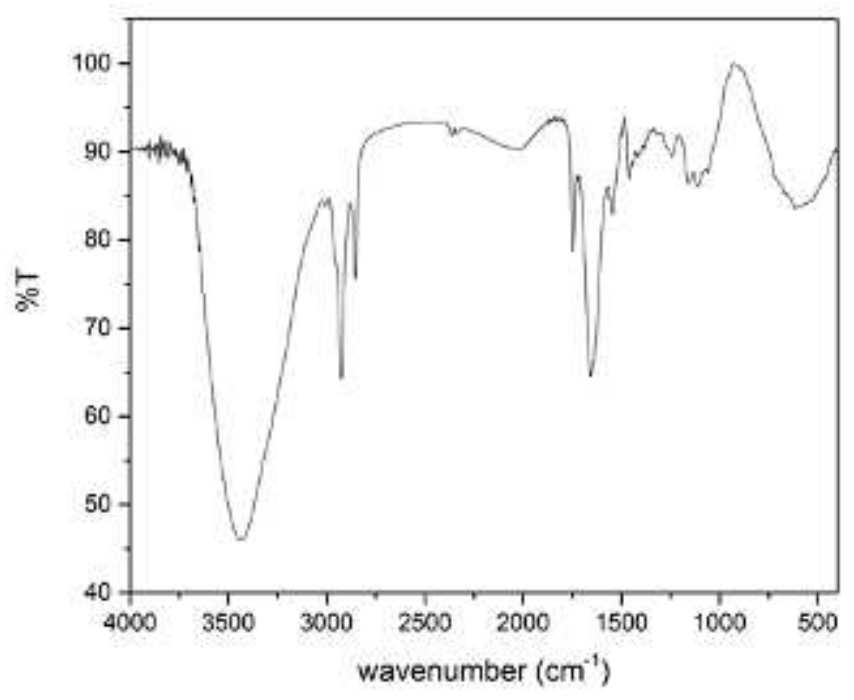

Fig. 2. FTIR spectra of papaya seeds powder

TABLE II

IR ABSORPTIONS OF SOME FUNCTIONAL GROUPS [30]

\begin{tabular}{|c|c|c|}
\hline \multicolumn{2}{|c|}{ Functional groups } & Wavenumber $\left(\mathrm{cm}^{-1}\right)$ \\
\hline $\mathrm{O}-\mathrm{H}$ & Alcohol & $3400-3650$ \\
\hline $\mathrm{N}-\mathrm{H}$ & Amine & $3300-3500$ \\
\hline $\mathrm{COOH}$ & Carboxylic acid & $2500-3100$ \\
\hline
\end{tabular}




\begin{tabular}{|c|c|c|}
\hline $\mathrm{C}=\mathrm{C}-\mathrm{H}$ & Alkene & $3020-3100$ \\
\hline $\mathrm{N}-\mathrm{H}$ & Amine salt & $2800-3000$ \\
\hline $\mathrm{C}-\mathrm{H}$ & Alkane & $2850-2960$ \\
\hline $\mathrm{C}=\mathrm{O}$ & Esters & $1735-1750$ \\
\hline $\mathrm{C}=\mathrm{C}$ & Alkene & $1648-1658$ \\
\hline
\end{tabular}

TABLE III

RESULTS OBTAINED FROM JAR TEST EXPERIMENT

\begin{tabular}{|r|r|r|r|}
\hline \multicolumn{1}{|l|}{ Run } & dosage (g/L) & \multicolumn{1}{l|}{ pH } & \multicolumn{1}{l|}{ \%removal } \\
\hline 1 & 0.5 & 2 & 82.3764 \\
\hline 2 & 0.25 & 2.5 & 36.8819 \\
\hline 3 & 0.85 & 2 & 79.1866 \\
\hline 4 & 0.5 & 1.29 & 60.2554 \\
\hline 5 & 0.5 & 2 & 80.5675 \\
\hline 6 & 0.75 & 2.5 & 52.083 \\
\hline 7 & 0.5 & 2.71 & 39.0506 \\
\hline 8 & 0.5 & 2 & 80.2369 \\
\hline 9 & 0.5 & 2 & 82.1198 \\
\hline 10 & 0.15 & 2 & 39.38 \\
\hline 11 & 0.75 & 1.5 & 64.2319 \\
\hline 12 & 0.5 & 2 & 81.2974 \\
\hline 13 & 0.25 & 1.5 & 75.0493 \\
\hline
\end{tabular}

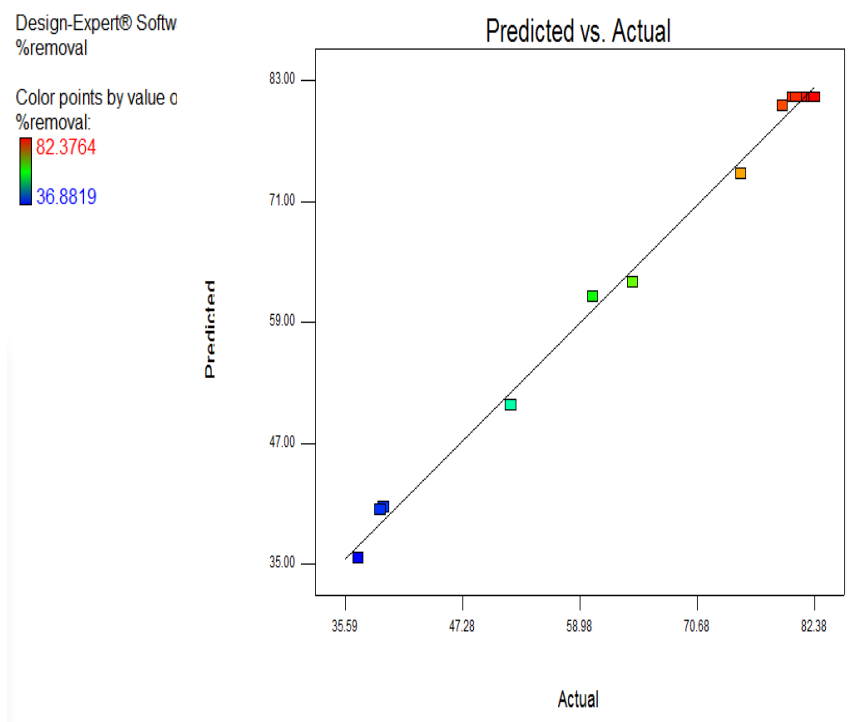

Fig. 3. Correlation between predicted $\%$ removal of the model and the experimental response

3-D response surface plot and its contour plot is presented in Fig $3 \mathrm{a}$ and $\mathrm{b}$, while the interaction curve is presented in Fig 3 c. It could be observed that when $\mathrm{pH}$ was above 2.5 , low \%removal was obtained, as can be observed from Fig 4. At the same dosage, with increased $\mathrm{pH}$ (Figure 3.b.), visually, lower \%removal was obtained, as the color was denser than Figure 3.c. At lower pH. When $\mathrm{pH} 4$ and dosage of $0.5 \mathrm{~g} / \mathrm{L}$ was used, only $1.15 \%$ removal was obtained.
It is known that in the coagulation process, the $\mathrm{pH}$ of the solution affects the surface charge of the coagulant and the dye [31]. It is possible at higher $\mathrm{pH}$; the coagulant was not protonated enough to ensure significant and efficient removal of dyes in the water.

DDR belongs to reactive dyes, which is anionic and water-soluble [20]. Its anionic property comes from the sulfonate functional group that would have a negative charge at lower $\mathrm{pH}$, thus strengthening elect,rostatic interaction between the dyes and papaya seeds powder as a coagulant. Papaya seeds' protein is high in glutamic acid, threonine, proline, and leucine [32] with its isoelectric point (pI) presented in Table 5. It is known that at $\mathrm{pH}$ below isoelectric points, amino acids would be protonated. Furthermore, these protonated amino functional groups from papaya seeds powder protein became positively charged and acted as a cationic polyelectrolyte. We speculate that adsorption followed by charge neutralization was the coagulation mechanism in this study. Similar results of $\mathrm{pH}$ effect to \%removal from the various study of anionic dyes coagulation were reported by other researchers [18], [25].

Variation of coagulant dosage was also significant to the dye removal. It is important to introduce optimum coagulant dosage into the water so that just enough polyelectrolytes present in the water to neutralize the particle so that the zeta potential is near zero. In this experiment, it was observed that at a dosage below $0.5 \mathrm{~g} / \mathrm{L}$, low \%removal was obtained. It could be explained that there were not enough polyelectrolytes present in the water to neutralize the dyes. As with the increase of papaya seeds powder dosage, higher \%removal was obtained. However, after its optimum condition, \%removal was decreased. We speculate that at high papaya seeds powder dosage in water, more soluble components (polyelectrolytes) was extracted, thus lowering its coagulation performance. This phenomenon could be caused by re-stabilization of colloid due to excessive polyelectrolytes in the water [18], [33]. The presence of excessive polyelectrolytes results in positive or negative zeta potential, thus reversing the effect of charge neutralization. The increase of coagulant dosage after its optimum concentration redispersion of particles was observed, thus lowering its \%removal. A similar effect of re-stabilization was also reported by other researchers[18], [34].

TABLE IV

ANOVA FOR THE CUBIC MODEL USED FOR DDR REMOVAL

\begin{tabular}{|l|r|r|r|r|l|}
\hline Source & $\begin{array}{l}\text { Sum of } \\
\text { Squares }\end{array}$ & df & $\begin{array}{l}\text { Mean } \\
\text { Square }\end{array}$ & F Value & $\begin{array}{l}\text { p-value } \\
(\text { Prob }> \\
\text { F) }\end{array}$ \\
\hline Model & 3926.1 & 7 & 560.885 & 165.4848 & $<0.0001$ \\
\hline $\begin{array}{l}\text { A- } \\
\text { Dosage }\end{array}$ & 792.28 & 1 & 792.282 & 233.7569 & $<0.0001$ \\
\hline $\mathrm{B}-\mathrm{pH}$ & 224.82 & 1 & 224.821 & 66.33194 & 0.0005 \\
\hline $\mathrm{AB}$ & 169.24 & 1 & 169.240 & 49.93313 & 0.0009 \\
\hline $\mathrm{A}^{\wedge} 2$ & 748.05 & 1 & 748.054 & 220.7078 & $<0.0001$ \\
\hline $\mathrm{B}^{\wedge} 2$ & 1604.0 & 1 & 1604.05 & 473.2641 & $<0.0001$ \\
\hline $\mathrm{A}^{\wedge} 2 \mathrm{~B}$ & 51.654 & 1 & 51.6543 & 15.24023 & 0.0114 \\
\hline $\mathrm{AB}^{\wedge} 2$ & 336.84 & 1 & 336.848 & 99.38451 & 0.0002 \\
\hline Residual & 16.946 & 5 & 3.38934 & & \\
\hline
\end{tabular}




\begin{tabular}{|l|r|r|r|l|r|}
\hline $\begin{array}{l}\text { Lack of } \\
\text { Fit }\end{array}$ & 13.451 & 1 & 13.4511 & R-Squared & 0.99570 \\
\hline $\begin{array}{l}\text { Pure } \\
\text { Error }\end{array}$ & 3.4955 & 4 & 0.87388 & $\begin{array}{l}\text { Adj R- } \\
\text { Squared }\end{array}$ & 0.98968 \\
\hline $\begin{array}{l}\text { Cor } \\
\text { Total }\end{array}$ & 3943.1 & 12 & & $\begin{array}{l}\text { Pred R- } \\
\text { Squared }\end{array}$ & 0.78029 \\
\hline
\end{tabular}

TABLE V

ISOELECTRIC POINTS FOR PAPAYA SEEDS’ AMINO ACIDS [35]
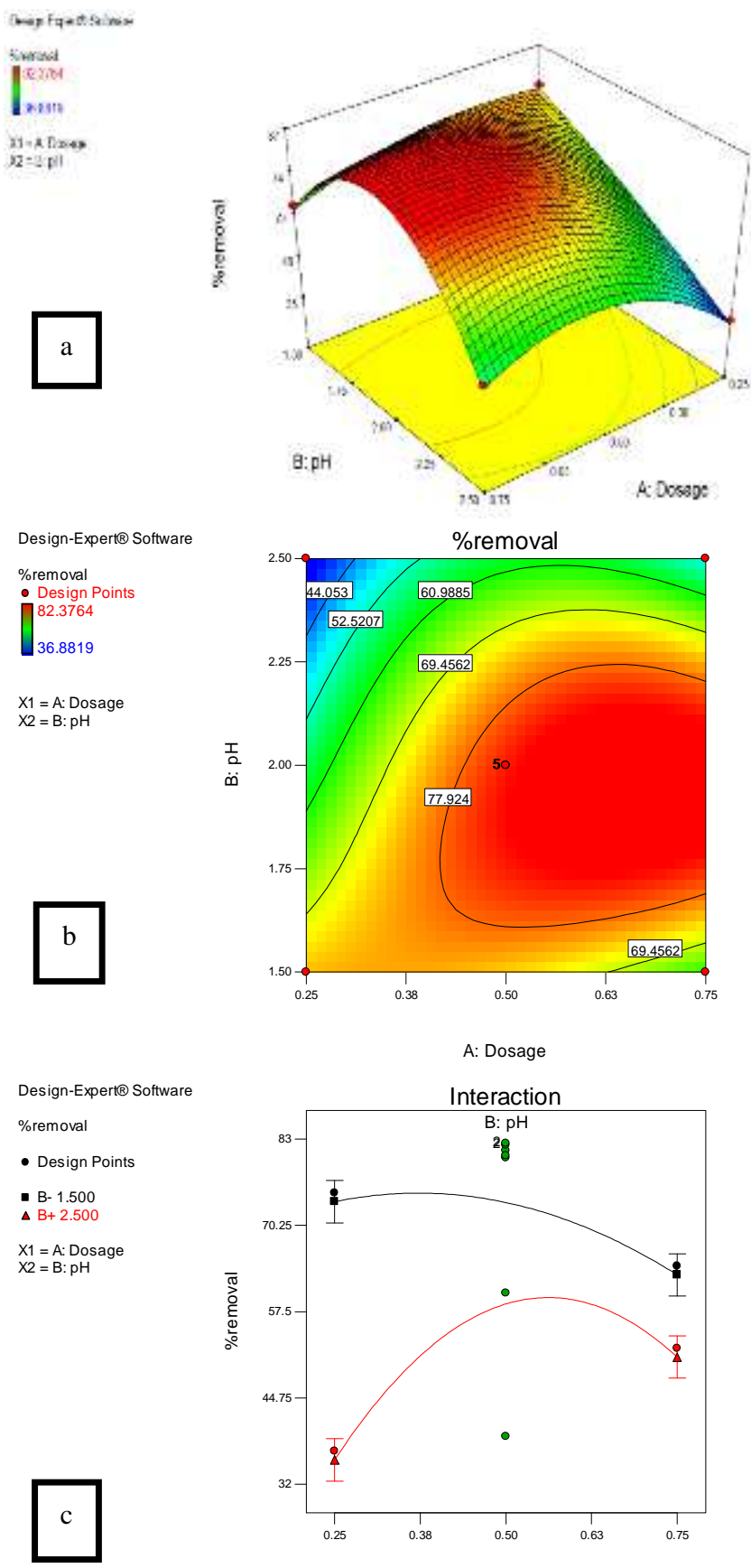

\begin{tabular}{|l|l|}
\hline Amino acids & pI \\
\hline Glutamic acid & 3.22 \\
\hline Threonine & 5.60 \\
\hline Proline & 6.30 \\
\hline Leucine & 5.98 \\
\hline
\end{tabular}

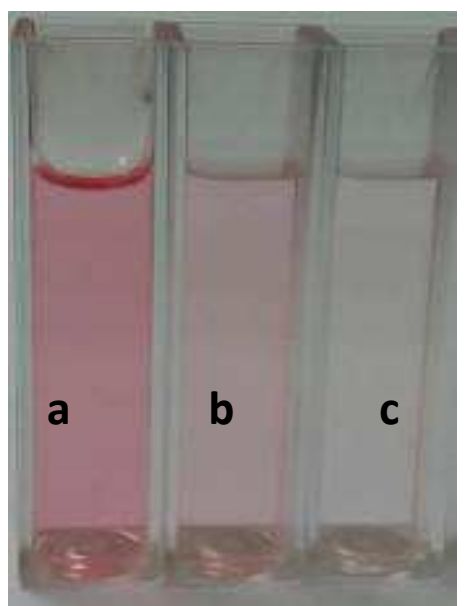

Fig 5. Visual observation of sample before (a) and after coagulation with $0.5 \mathrm{~g} / \mathrm{L} ; \mathrm{pH} 2.71$ (b), and $0.5 \mathrm{~g} / \mathrm{L} ; \mathrm{pH} 2$ (c)

From optimization, maximum color removal was obtained at $0.57 \mathrm{~g} / \mathrm{L}$ of coagulant dosage, and $\mathrm{pH} 1.97$ with $\%$ removal predicted to be $84.777 \%$. Confirmation of optimum condition was done in triplicate and gave $83.249 \pm 0.640 \%$ removal of DDR. This implies that this result was reproducible was with small deviation. Comparison of the result obtained in this study with various natural coagulants in previous studies is presented in Table 6. Although the comparison could not be directly made, however from Table 6 , it could be observed that papaya seeds powder has good potential to be used as a natural coagulant, as shown in relatively high \%removal. Further studies are required to identify the active coagulating agent from papaya seeds powder, extraction, and purification so that its utilization as natural coagulant would not increase oxygen demand value in the water after coagulation process. Furthermore, its application in real textile wastewater could be tested.

TABLE VI

COMPARISON \%REMOVAL OF VARIOUS NATURAL COAGULANTS

\begin{tabular}{|l|l|l|l|}
\hline $\begin{array}{l}\text { Natural } \\
\text { Coagulant }\end{array}$ & Dyes & $\begin{array}{l}\text { \% removal } \\
\text { at optimum } \\
\text { condition }\end{array}$ & Reference \\
\hline $\begin{array}{l}\text { Papaya seeds } \\
\text { powder }\end{array}$ & $\begin{array}{l}\text { Drimarene } \\
\text { dark red }\end{array}$ & $84.7 \%$ & This study \\
\hline Algal alginate & Congo red & $96 \%$ & {$[14]$} \\
\hline $\begin{array}{l}\text { Moringa } \\
\text { oleifera }\end{array}$ & Congo red & $83 \%$ & {$[15]$} \\
\hline $\begin{array}{l}\text { Moringa } \\
\text { stenopetala }\end{array}$ & Direct red 23 & $98.5 \%$ & {$[16]$} \\
\hline Potato starch & $\begin{array}{l}\text { C.I. Reactive } \\
\text { yellow 145A }\end{array}$ & $40 \%$ & {$[18]$} \\
\hline
\end{tabular}




\begin{tabular}{|l|l|l|l|}
\hline Okra & $\begin{array}{l}\text { Textile } \\
\text { wastewater }\end{array}$ & $93.57 \%$ & {$[19]$} \\
\hline $\begin{array}{l}\text { Ocimum } \\
\text { basilicum }\end{array}$ & Congo red & $68.5 \%$ & {$[31]$} \\
\hline Chitosan seed & Acid blue 92 & $99 \%$ & {$[33]$} \\
\hline $\begin{array}{l}\text { Surjana } \\
\text { powder }\end{array}$ & $98.0 \%$ & {$[36]$} \\
\cline { 1 - 1 } $\begin{array}{l}\text { Maize seed } \\
\text { powder }\end{array}$ & Congo red & $94.5 \%$ & \\
\hline Chitosan & Congo red & $95.1 \%$ & {$[37]$} \\
\cline { 1 - 1 } $\begin{array}{l}\text { Hibiscus } \\
\text { sabdariffa }\end{array}$ & Congo red & $95 \%$ & {$[38]$} \\
\hline $\begin{array}{l}\text { Azadirachta } \\
\text { indica }\end{array}$ & Neutral red & $90.2 \%$ & {$[39]$} \\
\hline $\begin{array}{l}\text { Descurainia } \\
\text { Sophia L. }\end{array}$ & Congo red & $96 \%$ & {$[40]$} \\
\hline $\begin{array}{l}\text { Acanthocerous } \\
\text { tetragonus }\end{array}$ & $\begin{array}{l}\text { Reactive } \\
\text { blue 19 }\end{array}$ & $95 \%$ & {$[41]$} \\
\cline { 3 - 3 } $\begin{array}{l}\text { Moringa } \\
\text { oleifera }\end{array}$ & $\begin{array}{l}\text { Reactive red } \\
120\end{array}$ & $97.2 \%$ & \\
\hline
\end{tabular}

[5] Dasgupta, J., J. Sikder, S. Chakraborty, S. Curcio, and E. Drioli, Remediation of textile effluents by membrane-based treatment techniques: A state of the art review. Journal of Environmental Management, 147, 55-72, 2015.

[6] Michalak, I., K. Chojnacka, and A. Witek-Krowiak, State of the Art for the Biosorption Process-a Review. Appl Biochem Biotechnol, 170(6), 1389-1416, 2013.

[7] Asghar, A., A.A.A. Raman, and W.M.A.W. Daud, Advanced oxidation processes the for in-situ production of hydrogen peroxide/hydroxyl radical for textile wastewater treatment: a review. Journal of Cleaner Production, 87, 826-838, 2015.

[8] Singh, K. and S. Arora, Removal of Synthetic Textile Dyes From Wastewaters: A Critical Review on Present Treatment Technologies. Critical Reviews in Environmental Science and Technology, 41(9), 807-878, 2011.

[9] Solís, M., A. Solís, H.I. Pérez, N. Manjarrez, and M. Flores, Microbial decoloration of azo dyes: A review. Process Biochemistry, 47, 1723-1748, 2012.

[10] Marcucci, M., I. Ciabatti, A. Matteucci, and G. Vernaglione, Membrane Technologies Applied to Textile Wastewater Treatment. Ann. N.Y. Acad. Sci., 984, 53-64, 2003.

[11] Meric, S., H. Selcuk, and V. Belgiorno, Acute toxicity removal in textile finishing wastewater by Fenton's oxidation, ozone, and coagulation-flocculation processes. Water Research 39, 1147-1153, 2005.

[12] Yin, C.-Y., Emerging usage of plant-based coagulants for water and wastewater treatment. Process Biochemistry, 45, 1437-1444, 2010.

[13] Asif, M.B., N. Majeed, S. Iftekhar, R. Habib, S. Fida, and S. Tabraiz, Chemically enhanced primary treatment of textile effluent using alum sludge and chitosan. Desalination and Water Treatment, 57, 72807286, 2016

We have successfully utilized papaya seeds powder as a natural coagulant for the removal of synthetic textile coloring agent wastewater. Papaya seeds powder contains some functional groups that indicate ate good possibility to be used as a natural coagulant. The model obtained from central composite design (CCD) was in good agreement with the experimental data, where coagulant dosage, $\mathrm{pH}$, and its interaction were found significant to the removal of color from the wastewater. Optimum condition was obtained at $0.57 \mathrm{~g} / \mathrm{L}$ coagulant dosage, and $\mathrm{pH} 1.97$ with the predicted removal of $84.77 \%$, which is in agreement with the experimental response value. Further study is needed to confirm the active coagulating agent in papaya seeds and also its utilization in real textile wastewater.

\section{NOMENCLATURE}

$\mathrm{Ci}$ initial concentration

$\mathrm{Cf}$ final concentration

mg. $L^{-1}$ mg. $L^{-1}$

Greek letters

Star point in CCD

\section{REFERENCES}

[1] Verma, A.K., R.R. Dash, and P. Bhunia, A review on chemical coagulation/flocculation technologies for removal of color from textile wastewaters. Journal of Environmental Management, 93, 154168, 2012.

[2] Robinson, T., G. McMullan, R. Marchant, and P. Nigam, Remediation of dyes in textile e,uent: a critical review on current treatment technologies with a proposed alternative. Bioresource Technology, 77, 247-255, 2001.

[3] Hudaya, T., J. Anthonios, and E. Septianto, UV/Fenton photooxidation of Drimarene Dark Red (DDR) containing textile-dye wastewater. IOP Conf. Series: Materials Science and Engineering, 162, 012022, 2017.

[4] Imran, M., D.E. Crowley, A. Khalid, S. Hussain, M.W. Mumtaz, and M. Arshad, Microbial biotechnology for decolorization of textile wastewaters. Reviews in Environmental Science and Bio/Technology, 14(1), 73-92, 2015.
[14] Vijayaraghavan, G. and S. Shanthakumar, Performance study on algal alginate as a natural coagulant for the removal of Congo red dye. Desalination and Water Treatment, 57, 6384-6392, 2016.

[15] Vijayaraghavan, G. and S. Shanthakumar, Efficacy of Moringa oleifera and Phaseolus vulgaris (common bean) as coagulants for the removal of Congo red dye from aqueous solution. J. Mater. Environ. Sci., 6(6), 1672-1677, 2015.

[16] Dalvand, A., E. Gholibegloo, M.R. Ganjali, N. Golchinpoor, M. Khazaei, H. Kamani, S.S. Hosseini, and A.H. Mahvi, Comparison of Moringa stenopetala seed extract as a clean coagulant with Alum and Moringa stenopetala-Alum hybrid coagulant to remove direct dye from Textile Wastewater Environ Sci Pollut Res, 23(16), 1639616405, 2016.

[17] Ramavandi, B. and S. Farjadfard, Removal of chemical oxygen demand from textile wastewater using a natural coagulant. Korean J. Chem. Eng., 31(1), 81-87, 2014.

[18] Zafar, M.S., M. Tausif, M. Mohsin, S.W. Ahmad, and M. Zia-ul-Haq, Potato Starch as a Coagulant for Dye Removal from Textile Wastewater. Water Air Soil Pollut 226: 244, 226(8), 244, 2015.

[19] Freitas, T.K.F.S., V.M. Oliveira, M.T.F.d. Souza, H.C.L. Geraldino, V.C. Almeida, S.L. Fávaro, and J.C. Garcia, Optimization of a coagulation-flocculation process for treatment of industrial textile wastewater using okra (A. esculentus) mucilage as natural coagulant. Industrial Crops and Products, 76, 538-544, 2015.

[20] Freitas, T.K.F.S., C.A. Almeida, D.D. Manholer, H.C.L. Geraldino, M.T.F.d. Souza, and J.C. Garcia, Review of Utilization Plant-Based Coagulants as Alternatives to Textile Wastewater Treatment, in Detox Fashion, Textile Science and Clothing Technology, S.S. Muthu, Editor 2018, Springer Nature Singapore Pte Ltd. p. 27-79.

[21] Ikram, E.H.K., R. Stanley, M. Netzel, and K. Fanning, Phytochemicals of papaya and its traditional health and culinary uses - A review. Journal of Food Composition and Analysis, 41, 201-211, 2015.

[22] Marfo, E.K., O.L. Oke, and O.A. Afolabi, Chemical Composition of Papaya (Carica papaya) Seeds. Food Chemistry, 22, 259-266, 1986.

[23] Yongabi, K.A., D.M. Lewis, and P.L. Harris, Indigenous plant-based coagulants/disinfectants and sand filter media for surface water treatment in Bamenda, Cameroon. African Journal of Biotechnology, 10(43), 8625-8629, 2011.

[24] Kakoi, B., J.W. Kaluli, P. Ndiba, and G. Thiong'o, Banana pith as a natural coagulant for polluted river water. Ecological Engineering, 95, 699-705, 2016.

[25] Mudenur, C., L.G. Sorokhaibam, V. Bhandari, S. Raja, and V.V. Ranade, Green approach to Dye Wastewater Treatment using Biocoagulants. ACS Sustainable Chem. Eng., 4(5), 2495-2507, 2016. 
[26] Shak, K.P.Y. and T.Y. Wu, Coagulation-flocculation treatment of high-strength agro-industrial wastewater using natural Cassia obtusifolia seed gum: Treatment efficiencies and flocs characterization Chemical Engineering Journal, 256, 293-305, 2014.

[27] Fatombi, J.K., B. Lartiges, T. Aminou, O. Barres, and C. Caillet, A natural coagulant protein from copra (Cocos nucifera): Isolation, characterization, and potential for water purification Separation and Purification Technology, 116, 35-40, 2013.

[28] Subramonian, W., T.Y. Wu, and S.-P. Chai, A comprehensive study on coagulant performance and floc characterization of natural Cassia obtusifolia seed gum in treatment of raw pulp and paper mill effluent. Industrial Crops and Products, 61, 317-324, 2014

[29] Dave, N., V.A. Lorenz-Fonfria, G. Leblanc, and E. Padros, FTIR Spectroscopy of Secondary-Structure Reorientation of Melibiose Permease Modulated by Substrate Binding Biophysical Journal Volume, 94, 3659-3670, 2008

[30] McMurry, J., Organic Chemistry 9th Edition2016: Cengage Learning.

[31] Shamsnejati, S., N. Chaibakhsh, A.R. Pendashteh, and S Hayeripothe ur, the Mucilaginous seed of Ocimum basilicum as a natural coagulant for textile wastewater treatment. Industrial Crops and Products, 69, 40-47, 2015.

[32] Marfo, E.K., O.L. Oke, and O.A. Afolabi, Some Studies on the Proteins of Carica papaya Seeds. Food Chemistry, 22, 267-277, 1986.

[33] Szygula, A., E. Guibal, M.A. Palacin, M. Ruiz, and A.M. Sastre, Removal of an anionic dye (Acid Blue 92) by coagulationflocculation using chitosan. Journal of Environmental Management, 90, 2979-2986, 2009

[34] Meraz, K.A.S., S.M.P. Vargas, J.T.L. Maldonado, J.M.C. Bravo, M.T.O. Guzman, and E.A.L. Maldonado, Eco-friendly innovation for nejayote coagulation-flocculation process using chitosan: Evaluation through zeta potential measurements. Chemical Engineering Journal, 284, 536-542, 2016

[35] Lundblad, R.L., and F.M. Macdonald, eds. Properties of Amino Acids. 4th edition ed. Handbook of Biochemistry and Molecular Biology2010, CRC Press: Boca Raton. 3-6.

[36] Patel, H. and R.T. Vashi, Removal of Congo Red dye from its aqueous solution using natural coagulants. Journal of Saudi Chemical Society, 16, 131-136, 2012.

[37] Yong, M.Y. and N. Ismail, Optimisation of Hibiscus Sabdariffa as a Natural Coagulant to Treat Congo Red in Wastewater. Journal of Engineering Science and Technology, 2, 153-165, 2016.

[38] Chethana, M., L.G. Sorokhaibam, V.M. Bhandari, S. Raja, and V.V. Ranade, Green approach to Dye Wastewater Treatment using Biocoagulants. ACS Sustainable Chem. Eng., 4(5), 2495-2507, 2016.

[39] Ahmadi, N., N. Chaibakhsh, and M.A. Zanjanchi, Use of Descurainia Sophia L. As a natural coagulant for the treatment of dye-containing wastewater. Environmental Progress \& Sustainable Energy, 35(4), 996-1001, 2016.

[40] Vijayaraghavan, G., P.V. Kumar, K. Chandrakanthan, and S. Selvakumar, Acanthocereus tetragonus an effective natural coagulan for Decolorization of synthetic dye wastewater Journal of Materials and Environmental Sciences, 8(9), 3028-3033, 2017.

[41] Jafari, A. and A.H. Mahvi, Reactive dyes (R. Blue 19 and R. Red 120) removal by a natural coagulant: Moringa oleifera. Environmental Engineering \& Management Journal, 14(10), 393-2398, 2015. 